\title{
Internationalization of Colombian Firms: Competitive and Productivity as a Problem to Enter the Asian Market
}

\author{
Saul Rick Fernandez Hurtado ${ }^{1} \&$ Luz Angela Martinez Martinez ${ }^{2}$ \\ ${ }^{1}$ Postdoc in Globalization and Regional Development, Center for Global Studies, Shanghai University, Shanghai, \\ China. PhD in Management Science and Engineering, Center for innovation and Knowledge Management, \\ Shanghai University, Shanghai, China. Professor and Researcher, Universidad Santiago de Cali, Cali, Colombia. \\ Research Seminar Coordinator "The Challenge of Research - tCR", Principal Project Researcher "Estudio de \\ viabilidad para la creación del centro estrategico de desarrollo del pacifico colombiano - CEDEPA", \\ Universidad Santiago de Cali, Cali, Colombia \\ ${ }^{2}$ Professional in Industrial Engineering, Department of Operations and Systems, Universidad Autónoma de \\ Occidente, Cali, Colombia
}

Correspondence: Saul Rick Fernandez Hurtado. E-mail: saulrick@163.com; luz_angela.martinez@uao.edu.co

Received: July 16, $2017 \quad$ Accepted: December 21, $2017 \quad$ Online Published: December 27, 2017

doi:10.5539/ass.v14n1p183 URL: https://doi.org/10.5539/ass.v14n1p183

\begin{abstract}
The main objective of this research is to identify the influence of the productivity and competitiveness level of Colombian firms in the development of Asian market. The approach used was through descriptive and empirical analysis, with respect to measured variables, which helps the understanding of what firms require the skills of productivity. As a result of this article, a need was obtained at the corporate and governmental level, that production line should have a change to the know-how (macro), which is a necessity for international business success. The research allows to conclude aspects relevant to business activities, where the correlation of strengthening firms-government-university, is producing a negative effect, and through the psycho-entrepreneurial acquisition.
\end{abstract}

Keywords: Competitiveness, financial system, globalization, international markets, productivity

\section{Introduction}

Globalization created independence for the different cultures that in times past were always questioned by their conditions of customs; during the era of slavery it was considered that the African culture had no right to anything, they only had the obligation to be slaves, this was because the predominant culture was that of the Spaniards or as they were called the blue blood, a measure of time to the end of slavery and with the times of struggle; today it can be found a variety of cultures and ethnic groups, today have their rights and own conditions of command, to this we owe the communication through books, art, among others.

This research presents the results about the productivity and competitiveness in the development of business environment, observing that today there are no firms can avoid globalization environment, an issue in which all the countries are participants in this global aspect (Lindh, 2017); globalization or economic opening, it is fundamental for the development and transformation of the national economy, for this reason, today it is necessary to have a suitable information for members active in international trade. It is precisely, for this reason, the interest to be entrepreneurs in the present does not have intercultural ignorance, thus avoiding the communication breaks between negotiations that hinder commercial exchange in turn, in the same way, all professionals who are part of a work team where its objective it's to be internationalized (Ramón-Llorens, García-Meca, \& Duréndez, 2017; Dominguez \& Mayrhofer, 2015).

It must have the necessary knowledge, that will provide the organization with an optimal level of market expansion, obtaining opportunities to grow and acquire positioning. A successful market expansion increases the level of productivity, incomes, and potential consumers, hence the important role by production capcity and the state must fulfill in order to guarantee adequate tools in the financial resources support, and with greater importance directed towards medium and small businesses.

In this way, the objective of the research is to determine and observe the shortcomings that are found in the 
productivity and competitiveness level on Colombian firms, at the time of developing competitive and productive firms, the purpose is to publicize the opportunities that the employer can have if properly trained and interested in know the government grants to access them, hence, the employer will develop strategies for the benefit of their organization and use of resources that will generate the goals with their favorable results.

For the development of the research there is a methodological proposal of an empirical type, carried out by a descriptive study, conducted by a deduction-hypothetical tool, which allows to analyze and identify the challenges of competitiveness and productiveness management in the internationalization activities of firms, without to fail to mention the need presented by firms to develop strategies that make them competent in relation to other firms already established and positioned in the Asian market, which increasingly competition increases due to globalization and lack of firm's information, that today are not productive to be competitive to enjoy the Asian consumers.

\section{Problem Statement}

Competitiveness and productiveness are the issue that takes relevance in the environment of business areas, fundamental as covering political, economic and social aspects of a nation, which consequently means that today, firms and organizations should strive to implement strategies of internationalization and to know Asian business culture. (Chen, Ong, \& Hsu, 2016), hat cover in a more specific and centralized way, all those determining and particular areas of each country; such as communication, clothing, cuisine, standards, and protocols characteristic of the Asian market, all this in order to obtain positive results in this internationalization, which in turn will allow to be competitive with other firms entering in the same market.

There are different problems, one of them is the weakness of productive capacity and the financial system (Tjaden \& Hunkler, 2017; Laouris \& Michaelides, 2017); since there is no link between the needs that are currently required in the international market and the way, in which the firms are organized with reference to this aspect; it should be taken into account that firms carry out specific activities of production and/or provision of services in different areas, and it requires that these be developed by highly qualified people in the position that corresponds to them; stimulation that exists on the part of the different institutions and organisms of the order both private and public, to give the solution to a problem that affects in a significant way, the commercial relations between the countries and therefore their economies (S Rick Fernandez, 2013), another worrisome aspect is the apathy that some entrepreneurs have for knowing and learning about other cultures; which sometimes falls to a decision more personal than entrepreneurial, where they see the interaction with other cultures, not so necessary to achieve and fulfill of business objectives.

\section{Justification}

As the selected problem developed, there were major problems in the productivity and financial support of the Colombian government, towards future entrepreneurs (Edsand, 2017), even professionals who exercise their careers without the means and necessary knowledge to carry out their activity in a consistent manner.

A productivity mechanisms in the business world are a fundamental pillar in business transactions, whether goods or services, leading to a successful agreement between the parties involved.

The Colombian state as a developing country has a long way to go in investing, both technological and investigative-processes, as expressed (Giotopoulos, Kontolaimou, Korra, \& Tsakanikas, 2017) around technological mechanisms, such as ICTs for the proper functioning of international negotiation processes, for an expansion of the population knowledge and greater preparation in each of the careers offered in the country, mainly those that touch on economic, social and administrative activities.

The main thing is to change the interests of the Colombian government to improve the institutional processes, providing the population with the necessary tools to grant a positioning of the country, both in the social environment for the suspicion and intelligence of its community, for the management of hostile environments as it can be generally the business agreements, as in the economic growth by exports and imports country' increase; increasing its capital and diminishing the deficit by the firms.

\section{Literature Review}

\subsection{Production Capacity and Financial System to be Competitiveness}

The globalization or commercial opening is a fundamental mechanism for the development and transformation of the economy of a country, therefore, the suitable form of the members that participate of the active way in the international trade; it is very important for the economic advancement of firms.

Hence the transcendental role of the financial institution and the State must fulfill (Monteiro, 2016); to guarantee 
the adequate instruments in the firms productivity, especially those SMEs who manage the international markets, and have little financial resources, but have high experience in the establishment of successful international relations, and thus in this way be able to contribute to the overcoming of the different flaws that have been observed in the course of trade agreements (Buzard, 2017; S. Rick, 2014).

One of the problems that most concerns are the ignorance and training in the cultural, social, and all those essential aspects of productivity and competitiveness that firms must take into account when implementing each of their strategies, which will allow them to penetrate other markets, diversify and expand their products and services.

Hypothesis 1a. The increase in production capacity makes the firms to be competitive in other markets, reinforcing the relationship of entrepreneurs at an international level regarding the number of business transactions (see Figure 1).

As can be seeing for a long time the productivity level, in general, has shortcomings that in the light of today have been minimal or few, the efforts on the part of the competent entities to support suitable firms in the different important markets, which would allow Colombia through its businesspeople and firms to achieve international competitiveness (Xu, Xia, \& Li, 2017; Carneiro, Rodrigues, \& Craig, 2017), issues such as science and technology are essential to achieve such competitiveness, as well as other fundamental factors such as research.

The current production capacity does not comply with international standards and requirements in terms of being internationalized and competitive in the market (Carneiro et al., 2017), in Colombia there is no financial support system focused fully on the emphasis of international business development and promotion, which encompasses the intercultural competencies of entrepreneurs in a consistent and appropriate manner, which would undoubtedly be of great benefit to the country's economic growth, in which first must guarantee the quality of products, make a reduction of tax and other internal government barriers.

Colombia has not been able to take advantage of these different channels of information to significantly attenuate the deficiencies that exist in the enterprise' environment, one of the proposals would be to establish or reaffirm existing ties or look for options and alternatives which help to correct such deficiencies.

Hypothesis $1 b$. The increase in financial support to the firms; minimizes the government care reflected in the number of business transactions (see Figure 1Figure 1. ).

Although it could be said that knowledge comes from experience and observation, to facilitate a behavior in the international market.

\subsection{Business support scenarios to join international market}

Currently, the most difficult thing to undertake in a market is the lack of projects knowledge in which the government has not made the management of making them known; the most suitable for entrepreneurs who have the initiative to undertake is to have clear and compelling information from their competitors, firms are part of our environment (Hsieh \& Hyun, 2018; S Rick Fernandez, 2016), although all are different and to be able to undertake a study is necessary where it covers larger dimensions to be able to enter a market that day by day is globalized.

Globalization has been rapid during the last decades, one of the biggest affluent has been the technological revolution of information and telecommunications that are experienced worldwide. The rapid growth of the market means that firms have higher levels in a production line, in order to be able to compete and gain position in a market.

Hypothesis 2a. All the lack of constant resources will negatively affect the business profitability (see Figure 1).

The environment of economic opening and of the firms constitute a scenario in which the phases of business management must be examined in an unusual way, in light of the challenges that arise from this environment (Vidgen, Shaw, \& Grant, 2017).

The government is concerned about achieving a greater economy where employment and productivity were generated in the country, Colombia has a strong economy but with many difficulties (Barjolle, Quiñones-Ruiz, Bagal, \& Comoé, 2017), therefore, an attempt was made to reduce protectionism, integration into the world (Saul Rick Fernandez, 2014; Ritzel \& Kohler, 2016) open markets and compete in search of a modern Colombia, thanks to that, today they face a world of big and small barriers that need to be overcome with a determination, if the same judgment with which started would have been maintained today, we would have a more refined country in its processes, agiler in its procedures and procedures, with fewer demands and better practices. 
Hypothesis $2 \mathrm{~b}$. All the constant cooperation at the governmental and financial level will positively affect the business profitability (see Figure 1).

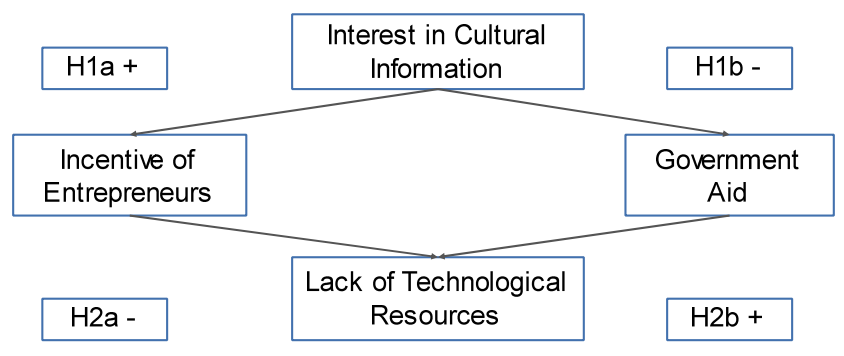

Figure 1. Research Model

The Colombian government has made many alliances where the free movement of goods and services is allowed, but for entrepreneurs who do not know the opportunities outside of borders, this means having psycho-business barriers (Guadix, Carrillo-Castrillo, Onieva, \& Lucena, 2015), this happens because of the ignorance of government projects; there are few firms that acquire these education projects and monetary aid, that is why so many opportunities are lost from new and competitive markets, because the initiatives are, but SMEs, unfortunately, do not have enough information to be part of government projects (Knight, Deng, \& Li, 2017; Felgueira \& Rodrigues, 2015), the innovative activity on the growth and performance of small companies of the countries coordinated by the Pacific Alliance has obtained an innovation result of its production, in processes and management that positively impacts: growth, employment, sales and likewise Its utility. It is true that Colombia has many commercial agreements, where an economic contribution could be made generating more employment, and more market opportunities that are still lost, that is why it is necessary to know our agreements with the other countries and to train ourselves to reach the objectives that every entrepreneurial firm wishes.

\subsection{Business innovation in order to be competitive}

As highlighted by Chan, Fong, Luk, \& Ho (2017); Oliveira, Echeveste, Cortimiglia, \& Gonçalves (2017), to be able to comply with this economic advance, organizations must identify a number of characteristics and requirements to become competent at a local level and, even more so, at the international level, among these characteristics we can highlight innovation as the main axis.

Cao, Navare, \& Jin (2017); Oliveira et al (2017) refers to innovation from the perspective of commercial firms and business organizations are the successful commercialization of an invention, entering a market or creating a new one, or improving internal processes and generating efficiency.

This is a differentiating point between one firm and another in a market that is globalized and saturated with innovative products, services, and processes; it is must bear in mind that innovation goes beyond the incorporation of technology, but also focuses on anticipating the needs of the globalized world, where consumers are more demanding, and therefore what will allow it to remain in the market National and international.

Busom \& Vélez-Ospina (2017), Giovannetti \& Piga (2017); Feder (2016); S. Rick (2014) mentions that productivity increases induced by innovation not only make the firms of a territory competitive, but also contribute to raising the standard of living of the citizens of that territory.

Productivity is a key factor and is undoubtedly aimed at innovation, which is why firms and governments must guide their strategies, policies, and resources to improve this failure greatly; that in addition to generating productivity, it generates that the organizations get to be competitive in the Asian markets.

In relation to the above, it is required that the investment in scientific, technological and research development in the firms be significant and find a collaboration of the different government levels, which provide the adequate tools, so the firms could compete effectively in Asia as a target market, because to get an innovation it needs the infrastructure and resources (capital and human) suitable.

However, coherent policies that are in accordance with all the innovative processes are also needed, as well as a regulatory framework that fosters the same, new strategic approaches of the new firms; and qualified personnel; given the above, firms will have the ability to participate in Asian markets with greater dynamics business; the firm-university-government, the latter must act in a synchronized manner, since each of them feeds on the others.

It is observed that for a long time the topic of innovation has become a focus of vital importance for the most developed countries, likewise, it analyzed by Oliveira et al (2017); Marxt \& Brunner (2013), that has allowed 
them to bring the subject to the forefront.

Regrettably, this process of industrialization in Colombia has developed gradually; which does not allow it to keep pace with global economic developments. The international context shows that the highest levels of development are possessed by those countries that enjoy high rates of innovative entrepreneurship in their economies. Colombia must identify and make an exhaustive diagnosis at the business level on the critical points in which it is necessary to act and correct, which will allow reaching markets such as Asians Andonova \& Ruíz-Pava (2016); Aggarwal, Berrill, Hutson, \& Kearney (2011).

The position was taken by some entrepreneurs in relation to the international negotiations they carry out, in a certain way influence, not only economically but also affects the small entrepreneurs and entrepreneurs that are making their way in this business field (Yang \& Gabrielsson, 2017), and it is because of this, that the ideal production line is emphasized.

\section{Methodology}

When carrying out the research, the descriptive methodology was used as well as empirical and it was taken out through a hypothetical-deductive study, which helped to identify the current state of firms' production and competitive level, since it is not what entrepreneurs expect.

\subsection{Population sample}

The population sample consisted of 100 observations, of different production sector (goods and services), for which surveys were conducted with 5 questions, where was asked about how the current state is considered at the production and competitive level to develop Asian markets, as well as government barriers and financial support.

\subsection{Data collection and analysis of results}

Through the sample, the necessary tabulation was performed in order to obtain real, measurable and achievable data, resulting in the following analyzes:

Table 1. Collection of the sample

\begin{tabular}{lll}
\hline Description & Quantity & Percentage \\
\hline Questionnaires sent (1) & 135 & \\
Questionnaires not available & 13 & $9,6 \%$ \\
Questionnaires received (1) & 122 & $90,4 \%$ \\
Forwarded questionnaires (follow-up) & 13 & $9,6 \%$ \\
Questionnaires received (2) & 11 & $8,1 \%$ \\
Total Questionnaires sent (1) - (2) & 148 & $10,1 \%$ \\
Not respond & 15 & $69,6 \%$ \\
Responded & 103 & $1,4 \%$ \\
Questionnaires declined to participate & 1 & $0,0 \%$ \\
Questionnaires that didn't be available & 0 & $68,2 \%$ \\
Complete questionnaires & 100 & \\
\hline
\end{tabular}

Based on the sample of the research, it can be observed that there is dissatisfaction with the lack of productivity (see Figure 2) provided by the Colombian state, where the right financial system is not provided to be competitive and generate economic growth strategies; without it, it is observed under the spatial analysis that the lack of qualified government regulations are in a negative position, manifesting the need to obtain greater attention to the improvement of internal support by government and financial institutions, at present in 21 st century it is needed to implement firms-working team (not individualism).

At the moment of analyzing the results of the sample, it is concluded that today people with an aspiration to be entrepreneurs have great ignorance in cultural aspects, this demonstrating that on the part of the governmental support is not enough in order that the entrepreneurs have input in its business activities, as detailed in Figure 2, in the same way, there are no business incentives for their development and contributions to society, it can be seen that productivity is required and a higher level of technological resources is needed.

The following Table 2 Table 2 details the level of confidence of $95 \%$ with a margin of error $5 \%$ in the variables studied in the research.

Table 2 shows $95.0 \%$ confidence intervals for the means and standard deviations of each of the variables. These intervals delimit the sampling error in the estimates of the parameters of the populations from which the data come. It can be used to help to judge how accurately the population means and standard deviations have been 
estimated. The intervals assume that the populations from which the samples come can be represented by normal distributions. While the confidence intervals for the means are quite robust and not very sensitive to violations of this assumption, the confidence intervals for the standard deviations are very sensitive. The assumption of normality can be verified in the procedure of analyzing a variable.

Table 2. Confidence Intervals $95,0 \%$

\begin{tabular}{lllll}
\hline & Medium & Error Est. & Lower limit & Upper limit \\
\hline Incentive for entrepreneurs & 0,32 & 0,0468826 & 0,226975 & 0,413025 \\
Lack of qualified personnel & 0,57 & 0,049757 & 0,471271 & 0,668729 \\
Government regulations & 0,35 & 0,0479372 & 0,254882 & 0,445118 \\
Government aid & 0,41 & 0,0494311 & 0,311918 & 0,508082 \\
Lack of knowledge & 0,23 & 0,0422953 & 0,146077 & 0,313923 \\
Interest for cultural information & 0,38 & 0,0487832 & 0,283203 & 0,476797 \\
Lack of technological resources & 0,78 & 0,0416333 & 0,69739 & 0,86261 \\
\hline
\end{tabular}

Note: Error range of 5\%

Table 3. Inertia and Chi-square Decomposition

\begin{tabular}{cllllll}
\hline \multicolumn{5}{c}{ Singular } & \multicolumn{3}{c}{ Chi- } & Cumulative \\
\hline Dimension & Value & Inertia & Square & Percentage & Percentage & Histogram \\
\hline 1 & 0,5059 & 0,2560 & 1254,2977 & 80,3531 & 80,3531 & $* * * * * * * * * * * * * * * * * * * * * * *$ \\
2 & 0,1728 & 0,0298 & 146,2357 & 9,3682 & 89,7213 & $* * *$ \\
3 & 0,1390 & 0,0193 & 94,7306 & 6,0687 & 95,7899 & $*$ \\
4 & 0,1027 & 0,0106 & 51,6997 & 3,3120 & 99,1019 & $*$ \\
5 & 0,0430 & 0,0019 & 9,0679 & 0,5809 & 99,6828 & $*$ \\
6 & 0,0314 & 0,0010 & 4,8203 & 0,3088 & 99,9916 & $*$ \\
7 & 0,0052 & 0,0000 & 0,1304 & 0,0084 & 100,0000 & $*$ \\
TOTAL & & 0,3186 & 1560,982 & & & \\
\hline
\end{tabular}

Note: $\mathrm{p}$-value $<0,05^{* *}$ (confidence level 95\%)

Table 3 details dimensions 1 and 2, which have a higher accumulated score, therefore the second dimension is the one with the highest accumulated percentage, shows the percentage of the total variability, in this research a variability was obtained in the first pair (the first 2 dimensions) with a percentage of $89.7213 \%$, which shows that between the incentives for entrepreneurs and the lack of qualified personnel is concentrated as a central problem of research.

Table 4. Code of research variables

\begin{tabular}{ll}
\hline IAE & Incentive for entrepreneurs \\
\hline FPC & Lack of qualified personnel \\
REG & Government regulations \\
AYG & Government aid \\
CDC & Lack of knowledge \\
IIC & Interest for cultural information \\
FRT & Lack of technological resources \\
\hline
\end{tabular}

According to Table 4, codes are observed for each of the variables.

It is noted that the contribution of the lack of qualified staff provides visibility given that as noted in Figure 2, is part of a necessary component for business development, without hesitation, this is due to the low levels of internationalization that would allow us an exchange not only of goods and services (Shearmur, Doloreux, \& Laperrière, 2015; Meyer, Skaggs, Nair, \& Cohen, 2015), but also of governmental support, which is another detailed contribution in Table 3 and in relation to 错误!未找到引用源。 which shows the correlation it has with little access to business incentives, which would promote technological resources necessary for business development; instead of seeing this as a disadvantage, it should be an open mouth for all those who are willing to be big business (Côrte-Real, Oliveira, \& Ruivo, 2017), since Colombia is a country with great biodiversity and infinite possibilities to take advantage of this quality to make us known internationally. According to the research sample, it is considered that there is a lack of knowledge both to carry out a business activity and in the same way to obtain the resources to increase economic prospects (Varum, Rocha, \& Valente da Silva, 2014), therefore, incentives are lacking through the entities endorsed to have a support that does not mean higher business costs; on the other hand, we are aware that do not have the technology to compete with large multinationals, and for 
this, SMEs require support. It is clear that the economic level in Colombia is taken advantage by strong firms economically and technologically, which complicates competing with this type of firms, since its have a wide recognition; financing, with qualified personnel and high innovative capacity.

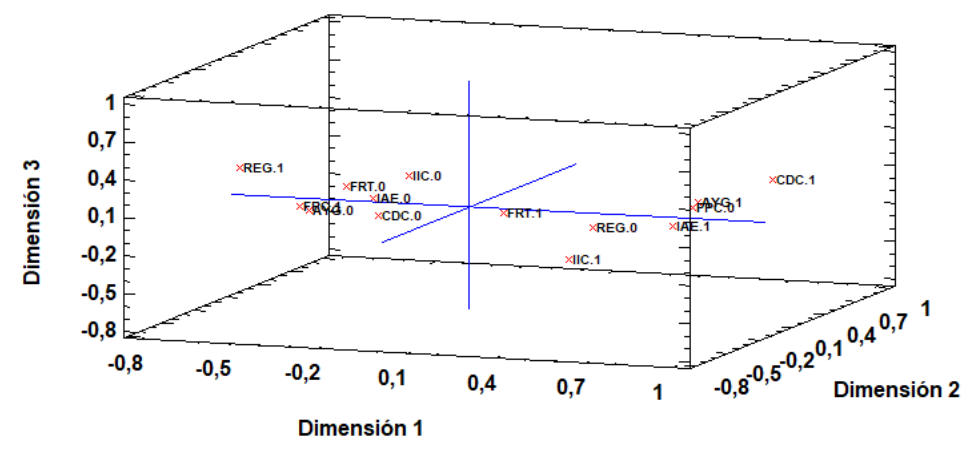

Figures 2. Correspondences Map - Space

Table 5. Category Contributions

\begin{tabular}{lllllllllll}
\hline & & & & & & Dim $\# 1$ & & \multicolumn{3}{c}{ Dim $\# 2$} \\
ID & Name & Quantity & Dough & Inertia & Coord & Corr & Contr & Coord & Corr & Contr \\
\hline 1 & IAE.0 & 0,807 & 0,097 & 0,040 & $-0,326$ & 0,806 & 0,040 & 0,010 & 0,001 & 0,000 \\
2 & IAE.1 & 0,807 & 0,046 & 0,086 & 0,693 & 0,806 & 0,086 & $-0,021$ & 0,001 & 0,001 \\
3 & FPC.0 & 0,979 & 0,061 & 0,116 & 0,767 & 0,977 & 0,141 & $-0,035$ & 0,002 & 0,002 \\
4 & FPC.1 & 0,979 & 0,081 & 0,088 & $-0,579$ & 0,977 & 0,107 & 0,026 & 0,002 & 0,002 \\
5 & REG.0 & 0,919 & 0,093 & 0,057 & 0,422 & 0,918 & 0,065 & $-0,015$ & 0,001 & 0,001 \\
6 & REG.1 & 0,919 & 0,050 & 0,105 & $-0,784$ & 0,918 & 0,120 & 0,027 & 0,001 & 0,001 \\
7 & AYG.0 & 0,966 & 0,084 & 0,081 & $-0,544$ & 0,965 & 0,098 & 0,018 & 0,001 & 0,001 \\
8 & AYG.1 & 0,966 & 0,059 & 0,117 & 0,783 & 0,965 & 0,140 & $-0,026$ & 0,001 & 0,001 \\
9 & CDC.0 & 0,910 & 0,110 & 0,031 & $-0,266$ & 0,781 & 0,031 & $-0,108$ & 0,129 & 0,043 \\
10 & CDC.1 1 & 0,910 & 0,033 & 0,105 & 0,892 & 0,781 & 0,102 & 0,363 & 0,129 & 0,145 \\
11 & IIC.0 & 0,751 & 0,089 & 0,038 & $-0,269$ & 0,527 & 0,025 & 0,175 & 0,224 & 0,091 \\
12 & IIC.1 & 0,751 & 0,054 & 0,062 & 0,439 & 0,527 & 0,041 & $-0,286$ & 0,224 & 0,149 \\
13 & FRT.0 & 0,768 & 0,031 & 0,058 & $-0,178$ & 0,054 & 0,004 & $-0,646$ & 0,714 & 0,439 \\
14 & FRT.1 & 0,768 & 0,111 & 0,016 & 0,050 & 0,054 & 0,001 & 0,182 & 0,714 & 0,124 \\
\hline It & necessar &
\end{tabular}

It is necessary to find a strategy to reduce unemployment and increase qualified personnel, it is vital to carry out an evaluation to the financial system (Schworm et al., 2017; Faham, Rezvanfar, Movahed Mohammadi, \& Rajabi Nohooji, 2016), so find the flaws and be able to develop and study business change solutions.

According to the results, there are several questions to study. The firms in the process of be productive are SME, to be qualified to enter into the internationalization markets, who can develop in the environment of their interest, but it find themselves with the wide ignorance of the governmental regulations adopted by the Colombian government; being thus, a great barrier in general is the ignorance of the extensions before the business activities to have access to the Asian markets. Of course, there are many firms with the desire to enter a market such as Asia, but do not have the necessary information, leaving the ideas and proposals on paper, since it does not know the processes duly parameterized to fix that idea. This is part of the integration firms, but also with great influence, in the scarce participation in the decision-making and the deficit of production, be it agreements, taxes, barriers, reforms, among others; making the citizen ignorant of the legal and regulatory issues of the country, giving him a great wall a long way to go, to be able to lower that curtain that the government has wanted to put to the corporate citizenship to make decisions without thinking about the welfare of society.

Therefore, most entrepreneurs today prefer to obtain a debt with a financial institution, because the incentives granted by the government are almost impossible (see Figure 2), a longer time in them, and in the end it is not known if the projects are suitable or simply the entities have an answer, does not meet the requirements. A large part of the sample does not know the aids and is not interested in looking for them or asking for information (see Table 5), the aid from government agencies is intended for firms that are already in business development. In relation to the above, it is clear that there is a flaw in the training system for employers, the lack of incentives for projects and the limited information provided by competent entities, therefore the contribution of the variable lack of qualified firms to enter an international markets. For the strengthening of firms, this variable (Table 5) as 
the main component is required to have greater attention, therefore the hypotheses correspond to the results of Table 6.

Table 6. Hypotheses measured in the investigation

\begin{tabular}{lll}
\hline Hypotheses 1a & $\begin{array}{l}\text { The increase in production capacity makes the firms to be competitive in other markets, } \\
\text { reinforcing the relationship of entrepreneurs at an international level regarding the number of } \\
\text { business transactions. }\end{array}$ & \\
\hline Hypotheses 1b & $\begin{array}{l}\text { The increase in financial support to the firms; minimizes the government care reflected in the } \\
\text { number of business transactions. }\end{array}$ & negative \\
\hline Hypotheses 2a & All the lack of constant resources will negatively affect the business profitability. & negative \\
\hline Hypotheses 2b & $\begin{array}{l}\text { All the constant cooperation at the governmental and financial level will positively affect the } \\
\text { business profitability. }\end{array}$ & positive \\
\hline
\end{tabular}

\section{Limitation of Research}

Limitations were observed when obtaining information to support financial resources by financial entities, which it was not possible to obtain for the study, data that could adjust the result of chi-square, providing an analysis with greater attention on integration business-financial entities-government; the financial system's responsibility to companies allows it to increase its participation in international markets, such as the Asian market. In future studies, it is expected to obtain the participation of financial entities, and that the data will help to resolve the dynamics of business internationalization. In addition, a great limitation was that the Colombian state does not present adequate policies to have an incentive on companies creating, in favor of being productive and competitive in markets outside of Colombia's borders, this presented by high taxes, restrictions, high bank charges and bureaucratic procedures, that impede companies with the vision to develop highly competitive markets.

\section{Conclusion and Implication}

According to the objectives, the following conclusions were reached:

The main shortcoming of cultural ignorance when making a negotiation is primarily by the minimum government support, with which Colombia has education, turning future professionals into ambiguous and ignorant personnel. In addition, the regulatory bodies of these support projects must take initiatives and change the selection process, making possible the incursion of people who do not have a suitable percentage of resources, but who have the ideal and motivation to perform them.

According to the sample, it is possible to analyze the bewilderment of small companies in the process of having high levels of productivity, and the resources provided an implication to get financial resources from the responsible entities and more attention from government; that is why, according to the percentages thrown, it is possible to deduce the nonconformities and concerns that companies have to have an adequate competitiveness in international markets such as Asia; it is very clear, that the world is in a moment of globalization, that is why it is necessary for both companies and regulatory bodies to concentrate on phases of evolution, to visualize goals and objectives to boost the country.

\section{Acknowledgements}

We would like to thank Dr. GUO Changgang from the Center for Global Studies at Shanghai University for his support to this study. We also would like to thank the General Direction of Research at Universidad Santiago de Cali and to the Department of Operations and Systems at Universidad Autónoma de Occidente for their contribution to the study.

\section{References}

Aggarwal, R., Berrill, J., Hutson, E., \& Kearney, C. (2011). What is a multinational corporation? Classifying the degree of firm-level multinationality. International Business Review, 20(5), 557-577. http://doi.org/10.1016/j.ibusrev.2010.11.004

Andonova, V., \& Ruíz-Pava, G. (2016). The role of industry factors and intangible assets in company performance in Colombia. J. of Bus. Res., 69(10), 4377-4384. http://doi.org/10.1016/j.jbusres.2016.03.060

Barjolle, D., Quiñones-Ruiz, X. F., Bagal, M., \& Comoé, H. (2017). The Role of the State for Geographical Indications of Coffee: Case Studies from Colombia and Kenya. World Development, 98, 105-119. http://doi.org/10.1016/j.worlddev.2016.12.006

Busom, I., \& Vélez-Ospina, J. A. (2017). Innovation, Public Support, and Productivity in Colombia. A Cross-industry Comparison. World Development, 99, 75-94. http://doi.org/10.1016/j.worlddev.2017.07.005 
Buzard, K. (2017). Self-enforcing trade agreements and lobbying. Journal of International Economics, 108, 226-242. http://doi.org/10.1016/j.jinteco.2017.07.001

Cao, L., Navare, J., \& Jin, Z. (2017). Business model innovation: How the international retailers rebuild their core business logic in a new host country. International Business Review. http://doi.org/10.1016/j.ibusrev.2017.10.005

Carneiro, J., Rodrigues, L. L., \& Craig, R. (2017). Assessing international accounting harmonization in Latin America. Accounting Forum, 4l(3), 172-184. http://doi.org/10.1016/j.accfor.2017.06.001

Chan, C. K. Y., Fong, E. T. Y., Luk, L. Y. Y., \& Ho, R. (2017). A review of literature on challenges in the development and implementation of generic competencies in higher education curriculum. International Journal of Educational Development, 57, 1-10. http://doi.org/10.1016/j.ijedudev.2017.08.010

Chen, P. H., Ong, C. F., \& Hsu, S. C. (2016). The linkages between internationalization and environmental strategies of multinational construction firms. Journal of Cleaner Production, 116, 207-216. http://doi.org/10.1016/j.jclepro.2015.12.105

Côrte-Real, N., Oliveira, T., \& Ruivo, P. (2017). Assessing business value of Big Data Analytics in European firms. Journal of Business Research, 70, 379-390. http://doi.org/10.1016/j.jbusres.2016.08.011

Dominguez, N., \& Mayrhofer, U. (2015, December 1). Internationalization stages of traditional SMEs: Increasing, decreasing and re-increasing commitment to foreign markets. International Business Review, pp. 1051-1063. Pergamon. http://doi.org/10.1016/j.ibusrev.2017.03.010

Edsand, H. E. (2017). Identifying barriers to wind energy diffusion in Colombia: A function analysis of the technological innovation system and the wider context. Technology in Society, 49, 1-15. http://doi.org/10.1016/j.techsoc.2017.01.002

Faham, E., Rezvanfar, A., Movahed Mohammadi, S. H., \& Rajabi Nohooji, M. (2016). Using system dynamics to develop education for sustainable development in higher education with the emphasis on the sustainability competencies of students. Technological Forecasting and Social Change, 123, 307-326. http://doi.org/10.1016/j.techfore.2016.03.023

Feder, C. (2016, May 19). The effects of disruptive innovations on productivity. Technological Forecasting and Social Change. North-Holland. http://doi.org/10.1016/j.techfore.2017.05.009

Felgueira, T., \& Rodrigues, R. G. (2015). Market Orientation of Teachers and Researchers in Higher Education Institutions: A New Approach. Procedia - Social and Behavioral Sciences, 174, 3017-3024. http://doi.org/10.1016/j.sbspro.2015.01.1092

Fernandez, S. R. (2013). It Takes Two to Tango : Commercial Relation Beyond Of Bilateral Agreement, China and Colombia to Sign a Free Trade Agreement. American Journal of Business and Management, 2(4), 275-295. http://doi.org/10.11634/216796061302426

Fernandez, S. R. (2014). 产业集群一体化挑战研究. CNKI JOURNAL. 上海大学. Retrieved from http://cdmd.cnki.com.cn/Article/CDMD-10280-1014418924.htm

Fernandez, S. R. (2016). The Opportunities and Bottlenecks between China and Latin American Countries' Economic and Trade Development. International Journal of Developing Societies, 5(2), 23-26. http://doi.org/10.11634/216817831605783

Giotopoulos, I., Kontolaimou, A., Korra, E., \& Tsakanikas, A. (2017). What drives ICT adoption by SMEs? Evidence from a large-scale survey in Greece. Journal of Business Research, 81, 60-69. http://doi.org/10.1016/j.jbusres.2017.08.007

Giovannetti, E., \& Piga, C. A. (2017). The contrasting effects of active and passive cooperation on innovation and productivity: Evidence from British local innovation networks. International Journal of Production Economics, 187, 102-112. http://doi.org/10.1016/j.ijpe.2017.02.013

Guadix, J., Carrillo-Castrillo, J., Onieva, L., \& Lucena, D. (2015). Strategies for psychosocial risk management in manufacturing. J. of Business Research, 68(7), 1475-1480. http://doi.org/10.1016/j.jbusres.2015.01.037

Hsieh, K.-Y., \& Hyun, E. (2018). Matching response to competitors' moves under asymmetric market strength. Journal of Business Research, 82, 202-212. http://doi.org/10.1016/j.jbusres.2017.09.038

Knight, J., Deng, Q., \& Li, S. (2017). China's expansion of higher education: The labour market consequences of a supply shock. China Economic Review, 43, 127-141. http://doi.org/10.1016/j.chieco.2017.01.008 
Laouris, Y., \& Michaelides, M. (2017). Structured Democratic Dialogue: An application of a mathematical problem structuring method to facilitate reforms with local authorities in Cyprus. European Journal of Operational Research. http://doi.org/10.1016/j.ejor.2017.04.039

Lindh, I. (2017). Entrepreneurial development and the different aspects of reflection. International Journal of Management Education, 15(1), 26-38. http://doi.org/10.1016/j.jjme.2016.12.001

Marxt, C., \& Brunner, C. (2013). Analyzing and improving the national innovation system of highly developed countries - The case of Switzerland. Technological Forecasting and Social Change, 80(6), 1035-1049. http://doi.org/10.1016/j.techfore.2012.07.008

Meyer, C. R., Skaggs, B. C., Nair, S., \& Cohen, D. G. (2015). Customer Interaction Uncertainty, Knowledge, and Service Firm Internationalization. Journal of International Management, 21(3), 249-259. http://doi.org/10.1016/j.intman.2015.04.003

Monteiro, L. H. A. (2016). Population dynamics in educational institutions considering the student satisfaction. Communications in Nonlinear Science and Numerical Simulation, 30(1-3), 236-242. http://doi.org/10.1016/j.cnsns.2015.06.015

Oliveira, L. S. de, Echeveste, M. E. S., Cortimiglia, M. N., \& Gonçalves, C. G. C. (2017). Analysis of determinants for Open Innovation implementation in Regional Innovation Systems. RAI Revista de Administração E Inovação, 14(2), 119-129. http://doi.org/10.1016/j.rai.2017.03.006

Ramón-Llorens, M. C., García-Meca, E., \& Duréndez, A. (2017). Influence of CEO characteristics in family firms internationalization. I. Business Review, 26(4), 786-799. http://doi.org/10.1016/j.ibusrev.2017.01.007

Ritzel, C., \& Kohler, A. (2016). Protectionism, how stupid is this? The causal effect of free trade for the world's poorest countries: Evidence from a quasi-experiment in Switzerland. Journal of Policy Modeling, pp. 1007-1018. http://doi.org/10.1016/j.jpolmod.2017.05.002

S. Rick, F. (2014). Empirical Result on Firms' Cluster Integration: Should Firms Evolve beyond Their Region? I. J. of Trade, Economics \& Finance, 5(3), 204-211. http://doi.org/10.7763/IJTEF.2014.V5.372

Schworm, S. K., Cadin, L., Carbone, V., Festing, M., Leon, E., \& Muratbekova-Touron, M. (2017). The impact of international business education on career success-Evidence from Europe. European Management Journal, 35(4), 493-504. http://doi.org/10.1016/j.emj.2017.02.009

Shearmur, R., Doloreux, D., \& Laperrière, A. (2015). Is the degree of internationalization associated with the use of knowledge intensive services or with innovation? International Business Review, 24(3), 457-465. http://doi.org/10.1016/j.ibusrev.2014.10.004

Tjaden, J. D., \& Hunkler, C. (2017, September 1). The optimism trap: Migrants' educational choices in stratified education systems. Soc. Sci. Res., 213-228. http://doi.org/10.1016/j.ssresearch.2017.04.004

Varum, C., Rocha, V. C., \& Valente da Silva, H. (2014). Economic slowdowns, hazard rates and foreign ownership. International Business Review, 23(4), 761-773. http://doi.org/10.1016/j.ibusrev.2013.11.008

Vidgen, R., Shaw, S., \& Grant, D. B. (2017). Management challenges in creating value from business analytics. European Journal of Operational Research, 261(2), 626-639. http://doi.org/10.1016/j.ejor.2017.02.023

Xu, X., Xia, Y., \& Li, C. (2017). Influence of Chinese entrepreneurial companies' internationalization on independent innovation: Input incentive effect and efficiency improvement effect. China Journal of Accounting Research, 10(3), 247-280. http://doi.org/10.1016/j.cjar.2017.05.001

Yang, M., \& Gabrielsson, P. (2017). Entrepreneurial marketing of international high-tech business-to-business new ventures: A decision-making process perspective. Industrial Marketing Management, 64, 147-160. http://doi.org/10.1016/j.indmarman.2017.01.007

\section{Copyrights}

Copyright for this article is retained by the author(s), with first publication rights granted to the journal.

This is an open-access article distributed under the terms and conditions of the Creative Commons Attribution license (http://creativecommons.org/licenses/by/4.0/). 